\title{
Protection of industrial electrical machines from flooding in mines
}

\author{
Nikolay SHAITOR ${ }^{1^{*}}$ and Dariusz WIECCEK ${ }^{2}$
}

\author{
Authors' affiliations and addresses: \\ ${ }^{1}$ Department of Renewable Energy Sources and \\ Electrical Systems and Networks, Institute of \\ Nuclear Energy and Industry, Sevastopol State \\ University, Kurchatova 7, 299015, Republic of \\ Crimea, Russia \\ e-mail: shaytor1950@mail.ru \\ ${ }^{2}$ Katedra Inżynierii Produkcji, Wydział Budowy \\ Maszyn i Informatyki, Akademia Techniczno- \\ Humanistyczna w Bielsku-Białej, ul. Willowa 2 \\ 43-309 Bielsko-Biała, Poland \\ e-mail: wiecekd@ath.bielsko.pl \\ *Correspondence: \\ Nikolay Shaitor, Department of Renewable \\ Energy Sources and Electrical Systems and \\ Networks, Institute of Nuclear Energy and \\ Industry, Sevastopol State University, Kurchatova \\ 7, 299015, Republic of Crimea, Russia \\ tel.: +79787155075 \\ e-mail: shaytor1950@mail.ru
}

\section{Acknowledgement:}

The author thanks the following people for their experience and assistance in all aspects of the research, as well as for their assistance in writing the manuscript.

Alexei Nikolaevich Strelnikov for experimenting with flooded electric machines.

Gokh Vitaly Anatolyevich for experiments with electric motors under pressure and valuable comments.

Ryaskov Yuri Ivanovich for non-standard technical solutions.

How to cite this article:

Shaitor, N. and Więcek, D. (2021). Protection of industrial electrical machines from flooding in mines. Acta Montanistica Slovaca, Volume 26 (3), 555-565

DOI:

https://doi.org/10.46544/AMS.v26i3.13

\begin{abstract}
Underground mining is associated with the risk of water entering mine workings. Dewatering plants ensure the safety of mining operations. They prevent flooding of mine workings. Therefore, electric dewatering pumps are considered an important type of processing equipment in underground mines and mines. Industrial electrical machines used in pumping and other installations are aircooled and cannot operate underwater. When such a unit is flooded, water destroys the electrical part. The author's ideas are implemented in the design of an electric motor with a dynamic air cushion in an electric cavity. Research is of particular value when used in offshore subsea mining complexes. Full-scale experiments with asynchronous motors for flooding depths of up to 100 meters, at appropriate air cushion pressures, have been carried out. A simulation model has been developed that allows one to determine the temperature regimes of improved structures immersed at different depths. It has been established that industrial electrical machines are capable of reliably operating in watered mine workings and in shelf conditions at considerable depths with minor design changes. However, in this case, it is necessary to take into account the payload, rotation speed, thermal conductivity and kinematic viscosity of air, which determine the temperature portrait of an electric machine for different immersion depths. The results obtained will help to make decisions about permissible overloads or restrictions when operating electric machines under water. Compliance with these recommendations will preserve the life of electrical machines when flooded. Proposed are substantiated design solutions of technical devices that ensure longterm operation of electric motors flooded in mine workings. These solutions make it possible to increase the safety of work when watering mine workings.
\end{abstract}

\section{Keywords}

drainage pumps; asynchronous electric motor; dynamic air cushion; work under water; simulation model; flooding safety.

(C) 2021 by the authors. Submitted for possible open access publication under the terms and conditions of the Creative Commons Attribution (CC BY) license (http://creativecommons.org/licenses/by/4.0/). 


\section{Introduction}

Underground mining is inextricably linked with the flow of water into mine workings (Ovchinnikov, 2017). This makes the mining process difficult and dangerous (Boloz and Bialy, 2020). The reliability of drainage systems and pumping equipment is one of the top priorities (Ovchinnikov and Smyslov, 2017; Ivanova and Zabinska, 2021). The channels of groundwater inflow are cracks of natural and technogenic origin (Zubov and Smychnik, 2015). The breakthrough of groundwater leads to the closure of mines and negative environmental consequences (Golovko, 2004; Dzhu et al., 2020, Kiss et al., 2014). When designing mine workings, it is impossible to take into account all the features of the properties of the rock mass (Pelipenko et al., 2019).

In the event of an emergency power outage, the operation of the drainage units stops, which can also lead to flooding of the mine (Yefremenko and Skrebneva, 2020). When working at depths of 1200-1600 meters, up to 56 stages of drainage are used (Onika and Khalyavkin, 2019). Pump failure at every stage increases the risk of flooding the entire mine. Ways must be found to reduce the risk of accidental flooding of electric motors in pumping stations. Dewatering plants ensure the safety of mining operations. They prevent flooding of mine workings (Dalganov, 2019). Therefore, electric dewatering pumps are considered an important type of processing equipment in underground mines and mines (Ovchinnikov, 2019).

Technological problems in the development of the Arctic shelf are caused by long-term ice fields. No proven subsea underwater technology exists to date (Kosareva et al., 2019). One of the directions of such technologies is the use of underwater complexes. However, a number of complex technical problems arise here (Shaitor et al., 2020). The power supply of the Arctic shelf is associated with nuclear ship technologies. Such solutions can ensure the safety and reliability (Oravec et al., 2021) of energy production for 15-25 years without reloading the fuel (Kovalchuk et al., 2020).

Electric drives with three-phase asynchronous motors of normal design are the most widespread in mining equipment. These motors are air-cooled and not designed to operate under water. When filing such a unit, water comes into contact with the electrical part. There is a decrease in insulation resistance, short circuit and destruction of electrical windings. Electrical windings cannot be restored. Replacing and repairing an engine takes a long time. It is required to create drainage pumping units capable of operating under water for a long time until the mine is completely drained. The main purpose of the submersible motor design is to protect the copper winding of the stator core from contact with water in order to prevent short circuits.

Electric motors of special types are designed for operation in liquid media. The hermetic centrifugal pump of the German company HERMETIC - Pumpen GmbH contains a rotor and an impeller on a common shaft. Plain bearings are lubricated with working fluid. The inner cavity of the stator and windings are protected from liquid ingress by a sealed screen. The group of Russian companies "NOVOMET", manufactures submersible oil-filled asynchronous motors for centrifugal pumps and electric centrifugal pumps for oil production (Panachev, 2019).

The American company Franklin Electric manufactures three types of electric motors for deep wells. Hermetically insulated Canned-type or Encapsulated Motor. The wound stator core is inserted into an outer stainless steel cylinder. Another very thin stainless steel inner cylinder fits into the stator gap. A wet winding motor (REW) contains special plastic winding wires. Electrical windings do not need to be sealed and are directly surrounded by liquid. The electric motor is oil-filled. The internal cavity is filled with oil. The oil provides bearing lubrication, cooling and electrical insulation.

Current ideas for subsea technology are the development of three main types of electrical machines or combinations thereof.

"Wet", with a flooded inner cavity, with the use of special reinforced insulation of the windings, preventing their contact with seawater, and special bearings.

"Oil-filled", with an internal cavity filled with special insulating liquids (oils), as well as with special shaft seals and expansion joints for liquids.

"Dry", using air in the inner cavity and volume expansion joints.

Existing submersible motors have the following disadvantages.

In "wet" type machines, reinforcement of the insulation reduces the cross-section of steel and copper and degrades the performance of the machine. Bearings in liquids with solid and aggressive impurities are unreliable. It is necessary to protect the stator and the rotor iron from destruction. Machines in aggressive environments are short-lived and unreliable.

"Oil-filled" machines require volumetric temperature compensation and a reinforced shaft seal. The machines are difficult to operate and are a source of environmental pollution due to oil leaks.

Dry machines also require volume temperature compensation and a reinforced shaft seal. The reliability of preventing flooding of internal cavities decreases with an increase in external pressure at greater depths of immersion.

The general disadvantage of the submersible machines under consideration is that they cannot operate in an air environment due to heating conditions. The cost of such machines is increasing. 
However, electrical machines for drainage pumping units are mainly operated on air. They fall under water only in conditions of flooding of mine workings. Therefore, the development of drainage pumping units, the engines of which can operate in universal air-water environments, is relevant.

The goal of the study is the development of industrial machines for performing functions in flooding conditions, the creation of a theoretical model asynchronous electric motor for operation under water, experimental confirmation of the model, development of practical options for operation.

\section{Material and Methods}

\section{Ideas and designs}

To maintain the performance of electric motors in water, the authors use an air cushion. This prevents water from entering the tight electrical cavity. The authors went further and came up with the idea of dynamically balancing the air pressure in the cavity and the water pressure. This important circumstance is caused by a change in the immersion depth when water enters the mine. (Cernecky et al., 2015) deals with air purification. Equal pressure on both sides of the cavity prevents its deformation, relieves the shaft seals, and ensures reliable protection of the windings and bearings. The effectiveness of the method increases with increasing immersion depth at high water pressure. This is especially important when used in subsea complexes for offshore mining.

Scientific analysis and forecasts of technological development show that the development of promising underwater technologies for electromechanical energy conversion can be built based on innovation and reconstruction of industrial electrical machines in combination with the development of new technical systems and devices that ensure their operation in water.

Deepwater technologies can be built on the principles of creating and maintaining an air cushion that prevents water from entering the internal electrical cavity of the machine (Fig. 1). If the motor is installed vertically with an exhaust hood, it is sufficient to close the ventilation opening with a tight cover. However, as the immersion depth increases, the air cushion contracts and the engine's bottom sinks into the water. The bearing is in water; grease is washed out from it, increased wear occurs. Water enters the electrical part.

To maintain an incompressible air cushion, it is necessary to maintain air pressure in the electrical part equal to the external water pressure. This requires a compressed air source. This reduces stress on the shaft seal and ensures reliable bearing performance. In addition, it is necessary to maintain the circulation of the cooling air to remove the heat generated in the electric machine and transfer the heat to the environment.
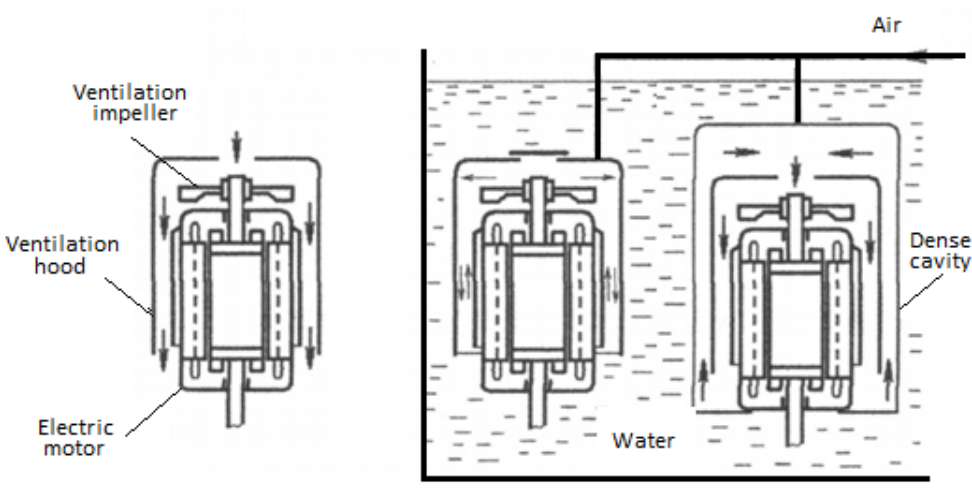

Fig. 1. Preservation of an incompressible air cushion

To maintain the performance of electric motors in water, the authors use an air cushion. This prevents water from entering the tight electrical cavity (Kuric et al., 2019). The authors went further and came up with the idea of dynamically balancing the air pressure in the cavity and the water pressure. This important circumstance is caused by a change in the immersion depth when water enters the mine. Equal pressure on both sides of the cavity prevents its deformation, relieves the shaft seals, and ensures reliable protection of the windings and bearings. The effectiveness of the method increases with increasing immersion depth at high water pressure. This is especially important when used in subsea complexes for offshore mining.

The method requires an air supply. It is advisable to store air in a high-pressure cylinder. The cylinder is attached to the electric motor. An air compressor can be used if required. In the case of an underwater production facility, a stationary air system is used.

There are various options for implementing this idea. One of the examples of the implementation of the authors' idea is shown in Fig. 2. The most difficult case is considered. The electric motor has a closed blowing design. An impeller is installed on the shaft for cooling the engine.

The electric motor 1 with the fan casing 2 is located inside cavity 3 . Fan 4 is installed on the motor shaft. On the other side of the shaft, there is a magnetic seal 5. The compensator 6 contains a spring 7, a differential 
diaphragm 8, a lever mechanism 9. One arm of the lever mechanism is connected to the stem of the air reducer 10. The other arm is connected to the stem of the etching valve 11 . The medium pressure air (MPA) port of the reducer 10 is connected to the cavity containing the electrical part. The gearbox inlet is connected to a high-pressure air (HPA) port. Ventilation holes with covers 12 are made in the cavity. Closing (opening) of the covers is provided by a pneumatic actuator 15 with a spring 16 . The actuator is started by a flooding sensor 13 and a pneumatic valve 14.

When engine 1 is operating under normal conditions, it is cooled in an open cycle with outside air. Cold air enters through the open axial hole in cavity 3 and in fan casing 2. The air is blown out by the fan 4 electrically and is removed through the radial holes (arrows at the top of the figure).

When flooding, the water pressure bends the membrane of the sensor 13 . The sensor moves spool 14 to the lower position. High-pressure air enters the pneumatic cylinder 15 . The pistons of the cylinder compress the spring 16 and close the cover 12. Engine 1 is ventilated in a closed circuit with internal air (arrows at the bottom of the figure). The internal air is cooled by the surrounding liquid through the cavity 3 .

During flooding, the compensator 6 comes into play. The diaphragm of the differential 8 bends upwards and compresses the spring 7. The right shoulder of the linkage mechanism 9 moves upwards, and the left - downwards. The left-hand linkage lever presses the piston rod of the diaphragm air regulator 10. The hole opens. The highpressure air pressure is reduced to medium pressure. Air flows from the reducer into the cavity 3 . The supply of air leads to an increase in pressure in cavity 3 , so the differential membrane 8 is bent downward. The right shoulder of the linkage mechanism 9 moves down, and the left - up. When equalising the air pressure in cavity 3 and the external water pressure, differential membrane 8 takes its original position. The left linkage lever stops the action of air on rod 10 of the diaphragm reducer. The hole closes, and the flow stops.

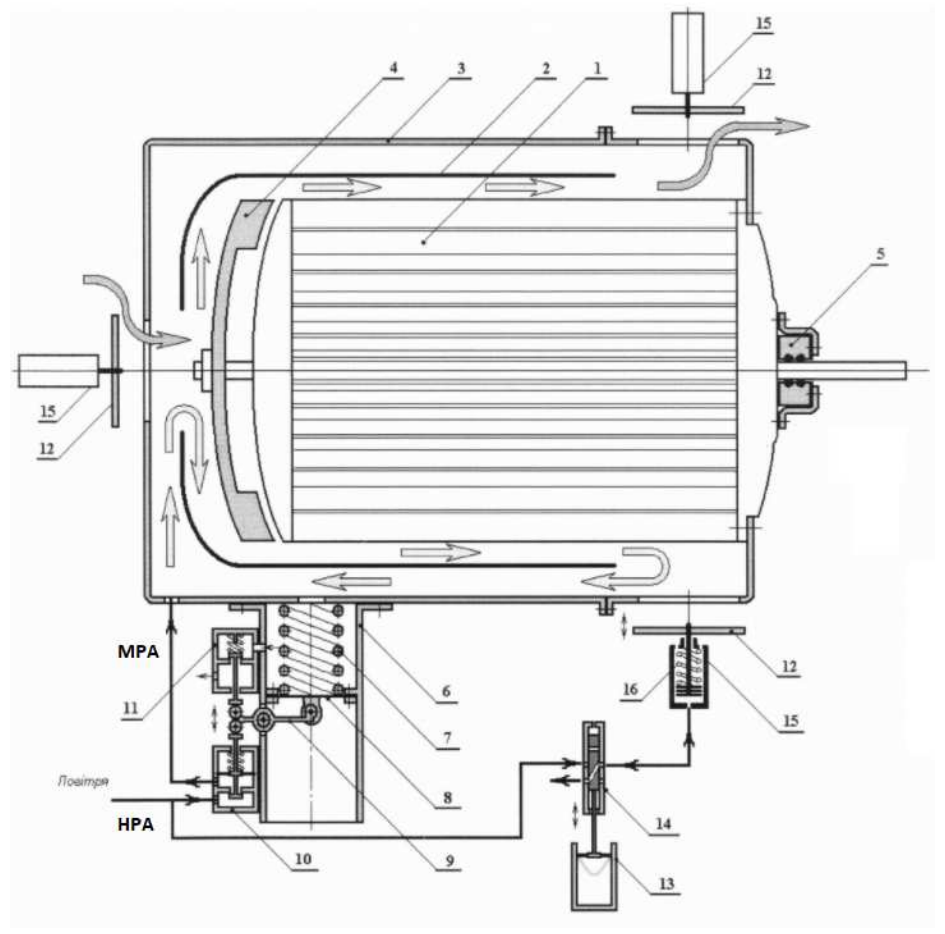

Fig. 2. Self-ventilated submersible motor

When the shaft is emptied, the water level and pressure decrease. The air pressure inside the cavity becomes greater than the external pressure. The diaphragm of the differential 8 moves downward and releases spring 7 . The right shoulder of the linkage mechanism 9 moves down, and the left one - up. The left lever of lever is pressed against the stem of the etch valve 11. Air exits through the hole. Inside and outside cavity 3 , the pressure is equalised.

The cycle repeats at variable depths of the sea shelf. This results in compressed air consumption. The disadvantage is eliminated using a compressor mounted on an electric motor. The compressor supplies exhaust air to the original cylinder. It can be powered by an electric motor (Akatov et al., 2019).

When the mine is completely drained, the membrane of flooding sensor 13 returns to its original position. The spool stem 14 moves up. It bleeds air from the cylinders 15. Under the action of the springs 16, the pistons of the cylinders return to their original position. Covers 12 open the ventilation holes in the hood 3. Ventilation of the engine is carried out in an open circuit. 
The scheme is greatly simplified for motors that do not have an external impeller 4 and a ventilation hood 2. Here, the engine housing 1 itself performs the task of a dense cavity 3 . The compensator 6 is installed directly on the engine. Compensator 6 is installed directly on the engine. Compressed air is supplied to the inside of the engine. Elements 3, 12,13,14,15 are excluded, which ensure the tightness of the cavity 3 .

The patented method protects electrical machines designed to operate under normal cooling air conditions. In accordance with the established thermal life of the insulation, the electric machine remains operational for 20 years or more. However, the temperature of the electrical windings must not exceed the maximum permissible temperature specified for the insulation class of the electrical machine.

In a flooded position, the ventilation of electric machines, according to the author's method, is carried out in a limited volume of a dense cavity cooled with water. In this case, the hydraulic resistance of the ventilation ducts and the cooling air flow rate change (Goldberg et al., 2001). With an increase in immersion depth, pressure increases, thermal conductivity and kinematic viscosity of the air increase. All of these physical factors have different effects on the heat generation, heat transfer and temperature of the motor windings. Some factors worsen, and others improve engine cooling. The result is unknown to us, requires research.

\section{Equivalent thermal circuits}

There are various software environments for calculating thermal fields based on numerical simulation. Finite element methods are most commonly used (Zienkiewicz, 1971). There are simple field programs with an extremely user-friendly interface that are easy to master. These are, first of all, the programs ELCUT, Quick Field, FEMME and others. Professional programs ANSYS, Flux 2D, Flux 3D, Femap have great capabilities but require effort to master them (Spodniak et al., 2021).

The thermal circuit method is preferred because of its simplicity, reliability, and sufficient accuracy. At the same time, it is easily integrated into the general simulation model of an asynchronous motor for underwater work, developed by the authors. It fits well with the ventilation calculation, as it is based on the Reynolds (Re), Nusselt $(\mathrm{Nu})$, Taylor (Ta) criteria. This allows you to solve research problems (Borisenko et al.,1983).

Thermal diagrams describe thermal transients between heat sources, structural elements and the environment. Heat flows in electric motors pass from the stator winding through the core to the casing, where they are removed by an air flow generated by an external blower. In addition, heat is transferred from the rotor to the stator through the air gap.

Heat sources are structural elements where energy losses occur. There are electrical, magnetic, and coolant movement losses in electric machines. Electrical losses are given by a current $I^{2}$ with a phase winding resistance $r:$

$$
\Delta P_{E}=I_{2} r=I^{2} \rho l / F,
$$

where $\rho$ - specific electrical resistance, $l$ - length of the core, $F$ - conductor cross-section.

Magnetic losses determine the magnetisation reversal of active steel by the main flow of an electric machine

$$
\Delta P_{M}=\kappa(P / M)_{10 / 50} B^{2}(f / 50)^{1,3} M
$$

where $\kappa$-correction factor; $(\mathrm{P} / \mathrm{M})_{10 / 50}-$ specific losses in steel per unit mass at induction of $1 \mathrm{~T}$ and a frequency of $50 \mathrm{~Hz}, B$ - average value of induction, $f$ - frequency, $M$ - core mass.

Ventilation losses are determined by the fan power:

$$
\Delta P_{V}=Q p / \eta_{2} \eta_{\text {об }} \eta_{\text {меx }}
$$

where $Q$ - air consumption, $p$ - full fan pressure, $\eta_{h}, \eta_{v}, \eta_{m}$ - its hydraulic, volumetric, mechanical efficiency.

Thermal circuits are widely known in the literature. As part of the thermal circuit, heat sources, branches and nodes. Heat flows go along the branches. They contain thermal resistance. Heat flows converge at the nodes.

An equivalent thermal circuit of $\mathrm{n}$ nodes, which simulates an electric machine as a thermal system, corresponds to a set of algebraic equations:

$$
\sum_{\kappa=1}^{n} a_{i, k} \Theta_{k}=\Delta P_{i},
$$

where $a_{i, k}$ - matrix elements, $\Theta_{\mathrm{K}}-$ the temperature at node $k, \Delta P_{i}-$ loss at node $i$.

Node losses consist of two types of losses: $\Delta P_{i}=\Delta P_{i}^{\prime}+\Delta P_{i 0}$. Temperature independent losses: $\Delta P_{i}^{\prime}$. Losses that depend on temperature: $\Delta P_{i 0}$. They are counted at ambient temperature (Zyuzev and Metelkov, 2015). 
Diagonal matrix elements

$$
a_{i, i}=\sum_{\substack{k=1 \\ k \neq i}}^{n}-a_{i, k}-\beta_{i} \Delta P_{i 0}
$$

know how to take into account the dependence of losses on temperature, using the temperature coefficient of losses $\beta_{i}$. Matrix elements outside diagonal are inversely proportional to thermal resistance with opposite sign:

$$
\left.a_{i, k}\right|_{i \neq k}=-1 / R_{i, k}
$$

Thermal resistances are determined for all elements of the electric motor. The thermal resistance of each element determines its material, geometry, and air flow rate. The temperature in each node that makes up an electric machine is found using a system of algebraic equations (1-5).

\section{Simulation model of an induction motor for underwater work}

To obtain data on the operation of electric machines under water under conditions of increased pressure, the path of theoretical and experimental research has been chosen. The research is based on the study of thermal phenomena (Gottfried, G., 1954). This is due to the fact that the insulation of the windings of electrical machines is very sensitive to temperatures and is the most vulnerable element (Dudkin et al., 2015). It is known that an excess of the winding temperature over the permissible value by only 10-12 degrees leads to a halving of the service life. Therefore, the criterion for performance was the maximum permissible overheating of the winding insulation (Saracheva et al., 2019). Theoretical studies were carried out on a mathematical simulation model, Fig. 3.

The model is intended for a comprehensive study of the temperature of electrical windings and the thermal resource of an induction motor under water. It includes an electric drive model and a thermal model. The input quantities are the parameters of the mechanical load, electrical and ventilation network.

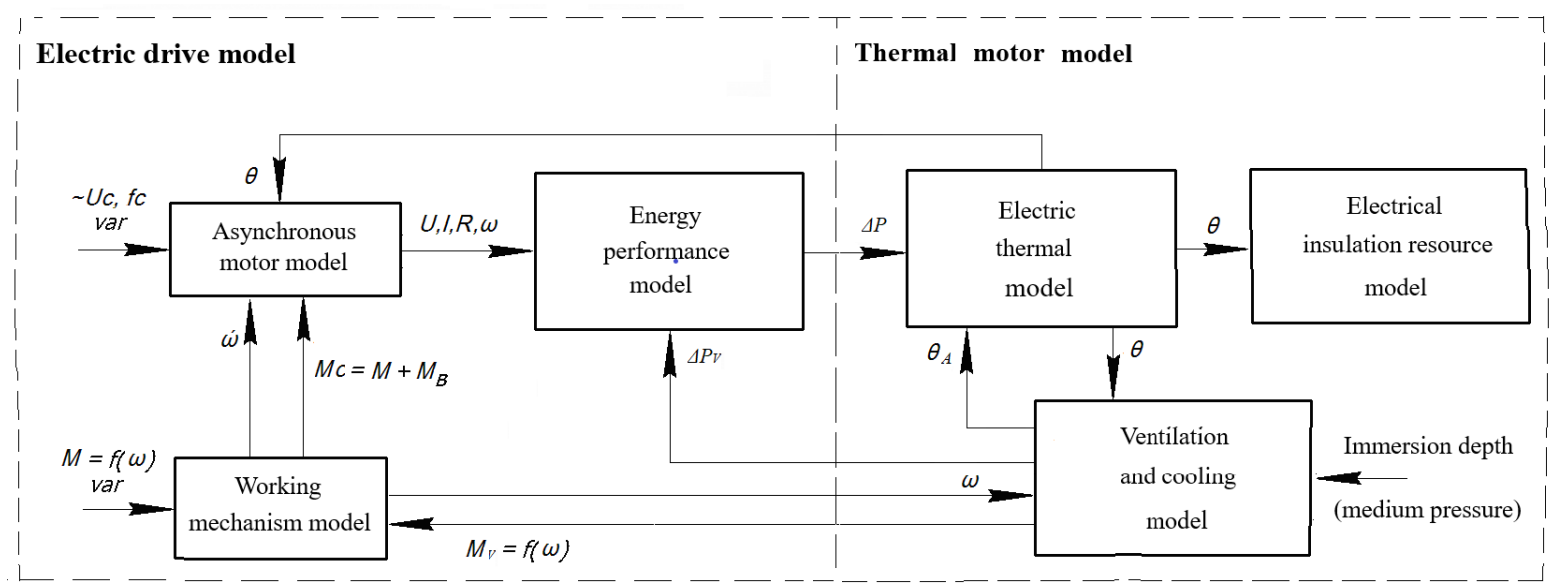

Fig. 3. Simulation model of an asynchronous motor for underwater work.

The electric drive model is presented in the form of three lower-level models: an induction motor model, a working mechanism model and an energy performance model (Chekunov, 1982).

The model of an asynchronous motor, according to the parameters of the equivalent circuit (Shubin et al., 2021), calculates the electrical resistance $R$ and the current $I$ of the windings, the mechanical characteristic of the motor $M=f(\omega)$. Variations are possible with a change in voltage $U$, electric frequency $f$, and angular frequency of rotation of the shaft $\omega$.

The model of the working mechanism sets the equation of the mechanical characteristics of the actuator $M c$ $=f(\omega)$ taking into account the ventilation moment of the cooling impeller of the engine Mr (Khitrov and Khitrov, 2019).

The energy efficiency model is used to calculate the power $P$, main and additional heat losses $\Delta P$ in the stator and rotor windings, cores and structural elements of the motor (Shaytor and Gorpinchenko, 2020).

The thermal model of the induction motor also consists of three lower-level models. It includes an electrical, thermal model, ventilation and cooling model, and an insulation system resource model (Pástor et al., 2020).

The electro-thermal model, according to the data of heat losses $\Delta P$ and the temperature of the cooling air $\theta_{A}$ makes it possible to determine the temperature of the insulation of the electric windings $\theta$ of the motor. 
The ventilation and cooling system model gives $\Delta P V$ losses for engine ventilation, cooling air temperature $\theta_{A}$. Input parameters are rotation speed $\omega$, the geometry of cooling channels, thermophysical and hydraulic characteristics of air, temperature and pressure (Sága et al., 2019).

The electrical Insulation Life Model gives an assessment of the electric motor for its further performance. This is possible with different inputs to the simulation model.

\section{Asynchronous motor ventilation}

The mathematical model of the ventilation system is an important element of the general mathematical model designed for a comprehensive study of an asynchronous electric motor. The self-ventilated industrial asynchronous motor under normal operating conditions is cooled by the impeller of an external fan according to the IC0141 scheme in an open cycle. In fig. 4 shows a variant of the vertical arrangement of the motor shaft. Cooling air from the environment enters through the central opening of the exhaust hood at the top. The fan impeller cools the fins of the motor housing as the air moves downward. The cooling air is heated by an electric motor. The heated air then escapes to the environment from under the lower part of the ventilation hood. Heat exchange between the rotor and the stator is carried out by the rotor impellers, which mix the internal air in the machine. The essence of open-loop ventilation is that the used outside air is no longer used. New air from the environment is supplied for cooling.

The electric motor is in a dense cavity immersed in water in the submerged state. The ventilation and cooling conditions are undergoing significant changes. In this case, the air used for cooling is not released into the environment but sent for reuse. It exits at the bottom of the ventilation hood and moves in the opposite direction, between the outer surface of the ventilation hood and the inner surface of the dense water-cooled cavity. It is becoming apparent that the cooling and heat transfer conditions have changed. When the ventilation conditions change, the hydraulic resistance of the ventilation ducts, the cooling air flow rate, and the power of ventilation losses, which affect the heating of the engine, change.

Features of calculating ventilation of an induction motor in an open and closed cycle are as follows. Under normal conditions in open circuit cooling, the flow $Q$ and head $h$ of an outdoor fan required to move air can be empirically determined

$$
\begin{aligned}
& Q=0,6(n / 1000)\left(D_{1} / 100\right)^{3} \cdot 10^{-2} \\
& h=12,3(n / 1000)^{2}\left(D_{1} / 100\right)^{2}
\end{aligned}
$$

where $D_{1}$ - is the outer diameter of the stator core, $\mathrm{m} ; n n$ - shaft rotation frequency, $\mathrm{rpm}$.

The fan power for creating air circulation can be approximated with sufficient approximation from the expressions

$$
P_{V}=Q h / \eta_{V}=0,9 \sum P_{M}
$$

where $\eta_{V}=0,5-0,6-$ efficiency of the fan; $\sum \mathrm{P}_{\mathrm{M}}=\mathrm{K}_{\mathrm{M}}(n / 1000)^{2}\left(D_{1} / 100\right)^{4}$ - mechanical losses (coefficientK $_{M}=1,3\left(1-D_{1} / 1000\right)$ at the number of poles $2 p=2$ and $\mathrm{K}_{M}=1$ at $2 p \geq 4$ ).

When filling and cooling the engine in a closed-loop (Fig. 4), the head of the cooler is equal to the sum of the head losses in successive sections of the hydraulic channel. With normal turbulent flow, the pressure loss in each section is proportional to the square of the flow:

$$
h_{1,2}=Z_{1,2} \cdot Q^{2}
$$

where $Z_{1,2}=\xi \gamma / 2 q_{2}^{2}$ - local hydraulic resistance at the transition from section 1 to section $2 ; \gamma$ - the density of the cooler; $q_{2}$ - channel cross-sectional area after local resistance; $\xi$ - coefficient of local resistance, determined by the configuration of the channel.

The heat transfer coefficient of a ribbed body $\alpha_{i}$ is determined by the Nusselt $N u_{i} \mathrm{Nu}_{i}$ number at the inlet and the hydraulic diameter of the channel $d_{h}$ from the equation

$$
\alpha_{i}=\mathrm{Nu}_{i} \cdot \lambda / d_{h}
$$

where $\lambda$ - coefficient of thermal conductivity of air; $d_{h}=4 F / \mathrm{Pe} d_{h}=4 F / \mathrm{Pe} ; F F$ - channel cross-sectional area; $\mathrm{PePe}$ - channel perimeter. 


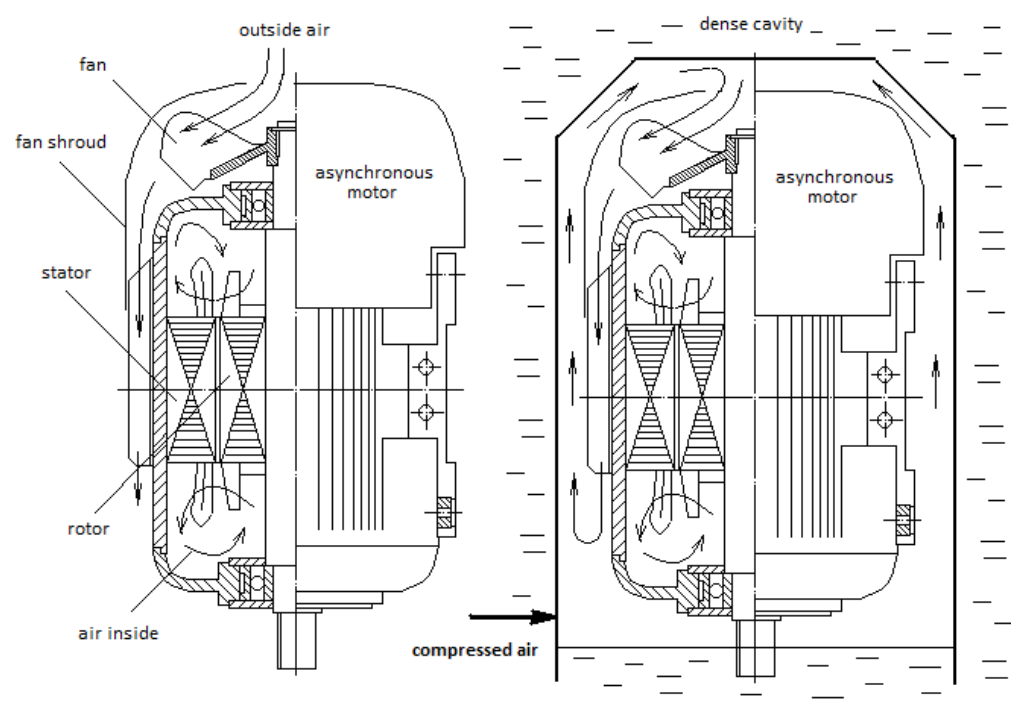

Fig. 4. Ventilation of an asynchronous motor under normal conditions and under water

The Nusselt number is a function of the flow turbulence in the boundary layer, which is characterised by the effective Reynolds number $R_{e} \mathrm{Re}_{e}$. For machines with a relatively small number of cooling fins, the Nusselt number is determined by the expression

$$
N u_{i}=0,627 R e_{e}^{0,52}
$$

The Reynolds number $R e_{e} \operatorname{Re}_{\mathrm{e}}$ is calculated from the effective speed $w_{e} w_{\mathrm{e}}$ and hydraulic diameter of the channel $d_{h} d_{h}$

$$
R e_{e}=w_{e} d_{h} / v \operatorname{Re}_{e}=w_{e} d_{h} / v
$$

where $v v$ - coefficient of kinematic viscosity of air; $w_{e}=\sqrt{w_{i}^{2}+\left(0,5 u_{v}\right)^{2}} w_{e}=\sqrt{w_{i}^{2}+\left(0,5 u_{v}\right)^{2}}$ - effective speed in channels; $w_{i} w_{i}$ - speed at the entrance to the channels; $u_{v}=\omega D_{v} / 2 u_{v}=\omega D_{v} / 2$ - peripheral fan speed; $\omega \omega$ - angular frequency of rotation of the engine.

The flow rate at the inlet to the ducts is determined by the air $Q Q$ flow generated by the fan and the supply air sectional area $F_{i} F_{i}$ :

$$
w_{i}=Q / F_{i}=Q /\left(\pi D_{v}^{2} / 4-F_{k} n_{k}\right) w_{i}=Q / F_{i}=Q /\left(\pi D_{v}^{2} / 4-F_{k} n_{k}\right)
$$

where $D_{v} D_{v}$ - outer diameter of the fan; $F_{k} F_{k}$ - cross-sectional area of the protrusion; $n_{k} n_{k}$ - number of ribs.

The air flow rate supplied by the fan for low and medium power motors is approximated by the formula

$$
\begin{aligned}
& Q=0,009 n D_{V} e^{-0,02 z_{p}} \operatorname{th}\left\{14,25 h_{k}^{2} n_{k} /\left[\left(n_{k}-1\right) t_{k} D_{2}\right]\right\} Q= \\
& 0,009 n D_{V} e^{-0,02 z_{p}} \operatorname{th}\left\{14,25 h_{k}^{2} n_{k} /\left[\left(n_{k}-1\right) t_{k} D_{2}\right]\right\},
\end{aligned}
$$

where $D_{2} D_{2}$ - is the outer diameter of the bed; $t_{k} t_{k}$ - rib step; $h_{k} h_{k}$ - rib height.

The calculated data (6-14) of the ventilation system enter the block of the electro-thermal model for the thermal calculation of the electric machine and the determination of the temperature of the "hottest" insulating element. Studies have shown that the most "hot" element of the insulation of induction motors is the insulation of the stator windings outside the slots.

\section{Results and Discussions}

The results of numerical studies are compared with the results of a full-scale experiment. For the experiment, asynchronous motors with squirrel-cage rotor AO2-31-2, AOMSh -21-2, AOMSh -22-4 were used. They have a closed airflow design and are designed to operate at atmospheric pressure (Likhachev, V. L., 2002). These motors 
are cooled by means of fins on the casing and an impeller on the shaft mounted inside the ventilation hood (Kuric, I., 2011). Such motors are cooled by means of fins on the housing and impellers on the shaft installed inside the ventilation casing (Fig. 4). The technical characteristics of the engines under study are shown in Tab. 1.

Tab. 1. Technical characteristics of the investigated engines

\begin{tabular}{|c|c|c|c|c|c|c|c|c|}
\hline $\begin{array}{c}\text { Electric motor } \\
\text { type }\end{array}$ & $\begin{array}{c}\text { Voltage } \\
{[\mathrm{V}]}\end{array}$ & $\begin{array}{c}\text { Amperage } \\
{[\mathrm{A}]}\end{array}$ & $\begin{array}{c}\text { Frequency } \\
{[\mathrm{Hz}]}\end{array}$ & $\begin{array}{c}\text { Net power } \\
{[\mathrm{kW}]}\end{array}$ & $\begin{array}{c}\text { Rotation } \\
\text { frequency } \\
{[\mathrm{rpm}]}\end{array}$ & $\begin{array}{c}\text { Power } \\
\text { factor }\end{array}$ & $\begin{array}{c}\text { Coefficient } \\
\text { useful action } \\
{[\%]}\end{array}$ & $\begin{array}{c}\text { Ultimately } \\
\text { permissible } \\
\text { temperature } \\
{\left[{ }^{\circ} \mathrm{C}\right]}\end{array}$ \\
\hline AO2-31-2 & $220 / 380$ & $11 / 6,1$ & 50 & 3,0 & 2880 & 0,89 & 84,5 & 120 \\
\hline AOMSh -21-2 & 380 & 1,75 & 50 & 0,7 & 2790 & 0,88 & 66 & 180 \\
\hline AOMSh -22-4 & 380 & 2,14 & 50 & 0,7 & 1370 & 0,8 & 66 \\
\hline
\end{tabular}

A full-scale experiment was carried out under the following conditions. The studies were carried out in the long-term operating mode of the S1 drive. The mechanical load was controlled by an electromagnetic brake mounted on the motor shaft (Zherve, 1984 and Goldberg, 2000). The net power on the shaft was set according to table 1. The electric motor was in a sealed air chamber. The chamber was kept at a constant temperature. Compressed air was supplied to the sealed chamber, and the air pressure was regulated by supply and etching valves. At a fixed pressure and a constant heating temperature, measurements were carried out using instruments. Air pressure $(\mathrm{Pa})$, power $P(\mathrm{~kW})$ consumed from the network, electric current $I(\mathrm{~A})$, rotation speed $n(\mathrm{rpm})$ and winding insulation temperature $\theta\left({ }^{\circ} \mathrm{C}\right)$ were measured. The insulation temperature was measured in the places of the greatest excess - on the frontal parts of the windings. The excess of the insulation temperature $\Delta \theta\left({ }^{\circ} \mathrm{C}\right)$ over the ambient temperature $\theta\left({ }^{\circ} \mathrm{C}\right)$ has been determined. The experiments were repeated with each successive increase in air pressure and while maintaining constant net power. The air pressure was increased to $11 \mathrm{x} 105 \mathrm{~Pa}$, which corresponds to a working immersion depth of more than 100 meters. The results of the study of engines are shown in Fig. 5.

We see good agreement between the calculation and experiment results. A reliable theoretical model of an electric motor in water has been obtained.

As a result of the study, it was found that with an increase in pressure, convective heat transfer and cooling in electric motors significantly improves. With an increase in pressure $\mathrm{Pa}$, the overheating temperature $\Delta \theta\left({ }^{\circ} \mathrm{C}\right)$ decreases intensively. This allows the use of motors with an overload of 1.5-2 times. This is permissible at a synchronous speed of asynchronous motors of $1500 \mathrm{rpm}$ (AOMSh-22-4).

With increasing pressure, the kinematic viscosity of the air increases. The electricity consumption for selfventilation is significantly increased, which provides additional heating. This is typical for asynchronous motors with a synchronous rotational speed of $3000 \mathrm{rpm}$ (AO2-31-2, AOMSh-21-2). With an increased pressure of 1.1 MPa (depth more than 100 meters), the power consumption of the A02-31-2 engine increased by 30\%, and the AOMSh-21-2 engine - by $40 \%$.
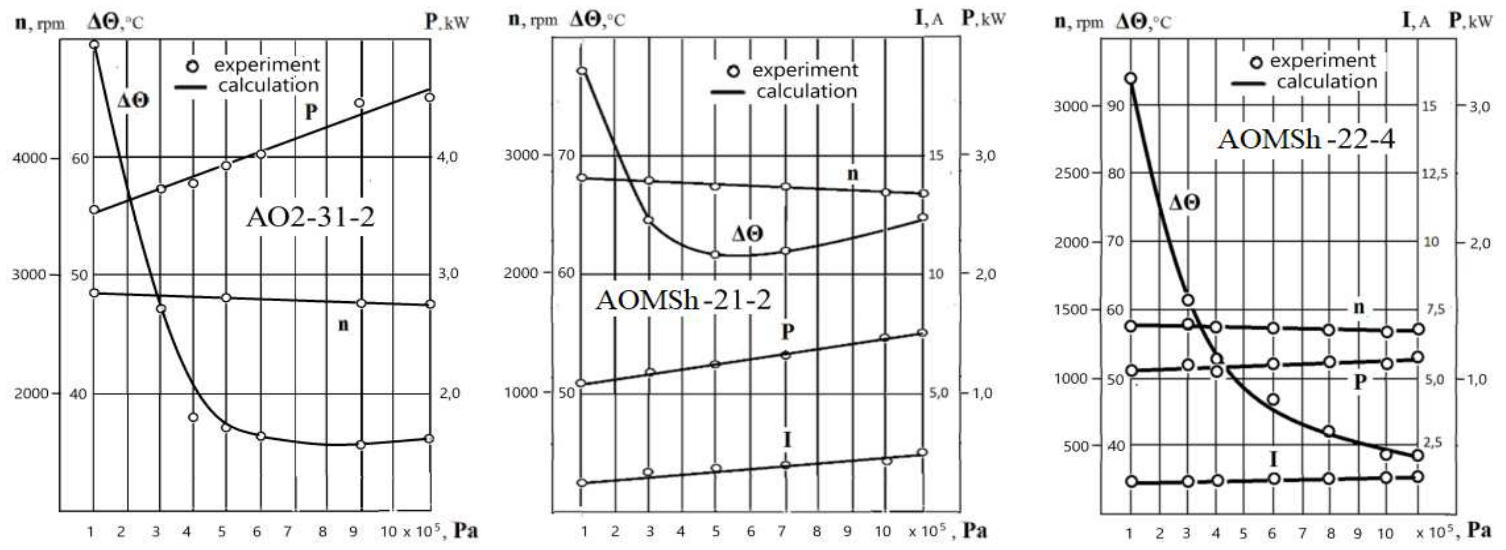

Fig. 5. Results of research of asynchronous motors for underwater work

At pressures of $0.3-0.5 \mathrm{MPa}$, the overheating temperature $\Delta \theta(\mathrm{C})$ of these motors slows down the decrease. From 0.6 to $0.8 \mathrm{MPa}$, the temperature begins to rise. Therefore, at a rotation speed of more than $1500 \mathrm{rpm}$ at depths of more than 50-60 meters, it is recommended to reduce the load to maintain the temperature regime. 


\section{Conclusion}

When an unprotected electrical machine is immersed in salt or seawater with good electrical conductivity, water seeps into the inside of the case and comes into contact with electrical windings and rotating parts. This increases the moment of resistance on the shaft of a running machine containing a ventilation impeller. This is compensated by multiple increases in electric current and is accompanied by increased overheating of the electrical windings. Due to overheating, the electrical insulation of the windings is destroyed, inter-turn short circuits and breaks occur in them. In electric collector machines, the collector-brush apparatus is actively destroyed. Bearing grease is flushed out, and increased bearing wear occurs. The operating time in salt and seawater depends on the type of unprotected electrical machine and is no more than 15-20 minutes, after which the machine cannot be restored.

Scientific analysis and forecasts of technological development show that the development of promising underwater technologies for electromechanical energy conversion can be built on the basis of innovation and reconstruction of industrial electrical machines in combination with the development of new technical systems and devices that ensure their operation in water.

In conclusion, it should be noted that industrial electrical machines are capable of reliably operating in watered mine workings and on the sea shelf at considerable depths. This requires minor design changes to create and maintain a dynamic air cushion in the electrical section. Thanks to this, industrial electric machines can be under water for an unlimited time while maintaining their performance. The theoretical simulation model makes it possible to reliably determine the temperature regimes of improved industrial asynchronous motors of various designs immersed at different depths. The results obtained are the basis for making a decision about possible overloads or restrictions when operating electric machines under water. Compliance with these recommendations will preserve the working life of electric machines during flooding in an air cushion. Constructive solutions of technical devices providing long-term operation of electric motors under water are proposed and substantiated. These solutions make it possible to increase the safety of work when watering mine workings.

\section{References}

Akatov, N.; Klačková, I.; Mingaleva, Z.; Galieva, G.; Shaidurova, N. (2019). Expert technology for risk management in the implementation of QRM in a high-tech industrial enterprise, Management Systems in Production Engineering, 27, p.p. 250-254.

Bołoz Ł., Biały W. (2020). „Automation and robotization of underground mining in Poland”. Applied Sciences 2020 vol. 10 iss. 20 pp. 1-14 p-ISSN: 2076-3417. DOI: 10.3390/app10207221

Borisenko, A. I., Kostikov, O. N., Yakovlev, A. I. (1983). Okhlazhdeniye promyshlennykh elektricheskikh mashin. Energoatomizdat, Moskva.

Cernecky, J., Valentova, K. Pivarciova, E and Bozek, P. (2015). Ionization Impact on the Air Cleaning Efficiency in the Interior. MEASUREMENT SCIENCE REVIEW, Volume: 15, Issue: 4, Pages: 156-166

Chekunov K.A. (1982) Teoriya morskogo elektroprivoda. Sudostroyeniye, Leningrad.

Dalganov, A.V. (2019). Ratsionalnaya chastota vrashcheniya tsentrobezhnykh nasosov shakht i rudnikov. Gornyy informatsionno-analiticheskiy byulleten, S9, p.p. 9-15. DOI: 10.25018 / 0236-1493-2019-5-9-9-15

Dudkin, A.N., Leonov, A.P., Supuyeva, A.S. (2015). Vliyaniye defektov v mezhvitkovoy izolyatsii na yeye stoykost $\mathrm{k}$ eksplutatsionnym nagruzkam, kharakternym dlya energoeffektivnykh sposobov upravleniya elektrotekhnicheskim oborudovaniyem. Izvestiya Tomskogo politekhnicheskogo universiteta. Inzhiniring georesursov, 326 (11), p.p. 83-89.

Dzhus, A., Rachkevych, R., Andrusyak, A., Rachkevych, I., Hryhoruk, O., Kasatkin, S. (2020). Evaluation the Stress-Strain State of Pumping Equipment in the Curvilinear Sections of the Wells. Management Systems in Production Engineering. Vol. 28, issue 3. pp. 189-195. DOI: 10.2478/mspe-2020-0028

Goldberg, O.D. (2000). Ispytaniya elektricheskikh mashin. Vysshaya shkola, Moskva. ISBN 5-06-003840-8.

Goldberg, O.D., Gurin, Y.S., Sviridenko, I.S. (2001). Proyektirovaniye elektricheskikh mashin. Vysshaya shkola, Moskva. ISBN 5-06-003842-4.

Golovko, I.V. (2004). Problemy vliyaniya na prirodnuyu sredu massovogo zatopleniya ugol'nykh shakht. Gornyy informatsionno-analiticheskiy byulleten, 6, p.p. 148-150.

Gottfried, G. (1954). Erwarmung und Kuhlung elektrischer Maschinen. Berlin-Heidelberg.

Ivanova T.N., Zabinska I. (2021). Modern Methods of Elimination of Lost Circulation in Directional Wells. Management Systems in Production Engineering. Vol. 29, issue 1. pp. 65-74. DOI: 10.2478/mspe-20210009

Khitrov, A.I., Khitrov, A.A. (2019). Opredeleniye parametrov elektromekhanicheskoy modeli asinkhronno-go dvigatelya. Vestnik Pskovskogo gosudarstvennogo universiteta. Seriya: Tekhnicheskiye nauki, 9,p.p.31-39.

Kiss, I., Wesely, E., Blistanova, M., (2014).Contribution to Logistics of Catastrophes in Consequence of Floods In: Procedia Engineering, no. 69, 2014, p. 1475-1480 
Kosareva, Y.V., Beskhizhko, V.V., Simakova, S.V., Chesnokov A.L. (2019). Podvodnyye dobychnyye kompleksy: kak perspektivnyy trend v osvoyenii arkticheskikh mestorozhdeniy i nekotoryye voprosy ikh elek-trosnabzheniya. Delovoy zhurnal Neftegaz.RU, 11 (95), p.p. 26-34.

Kovalchuk, M.V., Naraykin, O.S., Ustinov, B.C., Frolov, A.V., Kallar, YEL., Kushtan, V.V. (2020). Innovatsionnaya atomnaya energetika $\mathrm{v}$ preddverii shelfovykh proyektov $\mathrm{v}$ Arktike. Delovoy zhurnal Neftegaz.RU, 5 (101), p.p. 26-30.

Kuric, I. (2011). New methods and trends in product development and planning. 1st International Conference on Quality and Innovation in Engineering and Management (QIEM). Cluj Na-poca, 17.3.-19.3. 2011, p.p. 453-456, ISBN:978-973-662-614-2

Kuric, I.; Cisar, M.; Tlach, V.; et al. (2019). Technical Diagnostics at the Department of Automation and Production Systems. Book Series: Advances in Intelligent Systems and Computing, vol. 835, p.p. 474-484.

Likhachev, V. L. (2002). Elektrodvigateli asinkhronnyye. SOLON-R, Moskva. ISBN 5-93455-127-2.

Onika, S.P, Khalyavkin, F.G. (2019). Obosnovaniye i vybor sposoba osusheniya mestorozhdeniy poleznykh iskopayemykh ot pritokanykh vod. Gornaya mekhanika i mashinostroyeniye, 1, p.p. 18-23.

Oravec, M., Lipovsky, P., Smelko, M., Adamcik, P., Witos, M. Kwasniewski, J. (2021). Low-Frequency Magnetic Fields in Diagnostics of Low-Speed Electrical and Mechanical Systems. Sustainability, 13 (16)9197

Ovchinnikov, N.P. (2019). O prichinakh nizkoy ekspluatatsionnoy nadezhnosti sektsionnykh nasosov podzemnykh kimberlitovykh rudnikov. Problemy mashinostroyeniya i nadezhnosti mashin, 2, p.p 63-67. DOI: 10.1134 / S023571191902010X

Ovchinnikov N.P. (2017). Opyt ekspluatatsii sektsionnykh nasosov glavnogo vodootliva podzemnogo rudnika "Udachnyy". Vestnik Kuzbasskogo gosudarstvennogo tekhnicheskogo universiteta, № 3 (121), p.p.154162.

Ovchinnikov, N.P., Smyslov, A.G. (2017). Nekotoryye problemy ekspluatatsii nasosov glavnogo vodootliva podzemnogo rudnika "Udachnyy". Gornyy informatsionno-analiticheskiy byulleten, S24, p.p. 82-91. DOI: 10.25018 / 0236-1493-2017-11-24-82-91

Panachev, M. (2019). Obyemnyye nasosy novomet - novyye resheniya dlya neftedobychi. Delovoy zhurnal Neftegaz.RU, 6S (90), p.p. 52-55

Pástor, M.; Živčák, J.; Puškár, M.; Lengvarský, P.; Klačková, I. (2020) Application of Advanced Measuring Methods for Identification of Stresses and Deformations of Automotive Structures, In Journal; Applied Sciences, vol. 10 (21), article number 7510, MDPI, ISSN 2076-3417.

Pelipenko, M.V., Baloviyev, S.V., Aynbinder, I.M. (2019). K voprosu kompleksnoy otsenki riskov avarii na rudnikakh. Gornyy informatsionno-analiticheskiy byulleten', 11, p.p. 180-192. DOI: 10.25018 / 0236-14932019-11-0-180-192

Sága, M.; Vaško, M.; Handrik, M.; Kopas, P. (2019). Contribution to random vibration numerical simulation and optimisation of nonlinear mechanical systems, Scientific journal of Silesian University of Technology Series Transport 103, p.p. 143-154.

Saracheva, D.A., Vakhitova, R.I., Urazakov, K.R. (2019). Zavisimost' teplovogo sostoyaniya elektrotsentrobezhnogo nasosa ot chastoty vrashcheniya dvigatelya. Izvestiya Tomskogo politekhnicheskogo universite-ta. Inzhiniring georesursov, 330 (12), p.p. 103-110. DOI: 10.18799 / 24131830/2019/12/2406

Shaytor, N.M., Gorpinchenko, A.V. (2020). Dinamicheskiye rezhimy asinkhronnykh dvigateley v privodakh energeticheskikh sistem i kompleksov. Vestnik IzhGTU imeni M.T. Kalashnikova, 23 (4), p.p. 95-101. DOI: 10.22213 / 2413-1172-2020-4-95-101

Shaytor, N.M., Yakimovich, B.A., Ryaskov, Y.I., Gorpinchenko, A.V. (2020). Application of genetic engineering techniques in the development of complex electromechanical structures for marine robotics. Russian Journal of Nonlinear Dynamics, 16 (1), c 93-103. DOI: 10.20537 / nd200108

Shubin, S.S., Yamaliyev, V.U., Glazyrin, A.S., Bunkov, D.S., Kladiyev, S.N., Rakov, I.V., Bolovin, Y.V., Kovalev, V.Z., Khamitov, R.N. (2021). Opredeleniye parametrov skhemy za pogruzhnogo elektrodvigatelya na osnovanii dannykh ispytaniy. Izvestiya Tomskogo politekhnicheskogo universiteta. Inzhiniring georesursov, 332 (1), p.p. 204-214.

Spodniak, M., Semrád, K., Draganová, K. (2021). Turbine Blade Temperature Field Prediction Using the Numerical Methods. Applied Sciences-Basel, 11 (6), article number 2870. DOI10.3390/app11062870

Yefremenko, V.M., Skrebneva, Ye.V. (2020). Opredeleniye dopustimogo vremeni pereryva v elektrosnabzhenii shakhtnykh vodootlivnykh ustanovok. Naukoyemkiye tekhnologii razrabotki $i$ ispolzovaniya mineralnykh resursov, 6, p.p. 302-306.

Zherve, G.K. (1984). Promyshlennyye ispytaniya elektricheskikh mashin. Energoatomizdat, Leningrad.

Zienkiewicz, O. C. (1971). The Finite Element Method in Engineering Science. London: McGraw-Hill.

Zubov, V.L., Smychnik, A.D. (2015). Snizheniye riskov zatopleniya kaliynykh rudnikov pri proryvakh v gornyye vyrabotki podzemnykh vod. Zapiski Gornogo instituta, 215, p.p. 29-37.

Zyuzev, AM., Metelkov, V.P. (2015). Uchet kolebaniy temperatury obmotki statora na termicheskiy resurs asinkhronnogo dvigatelya. Elektrotekhnika: setevoy elektronnyy nauchnyy zhurnal, 2 (1), p.p. 62-71. 